\title{
Structural characteristics of marandu palisadegrass swards subjected to continuous stocking and contrasting rhythms of growth
}

Priscila de Mesquita ${ }^{1}$; Sila Carneiro da Silva ${ }^{2 *}$; Adenilson José Paiva ${ }^{1}$; Fábio Olegário Caminha ${ }^{1}$; Lilian Elgalise Techio Pereira ${ }^{1}$; Vítor Del’Álamo Guarda ${ }^{1}$; Domicio do Nascimento Júnior ${ }^{3}$

${ }^{1}$ USP/ESALQ - Programa de Pós-Graduação em Ciência Animal e Pastagens.

${ }^{2}$ USP/ESALQ - Depto. de Zootecnia. Av. Pádua Dias, 11 -13418-900 - Piracicaba, SP - Brasil.

${ }^{3}$ UFV - Depto. de Zootecnia, Av. P.H.Rolfs, s/n. - 36570-000 - Viscosa, MG - Brasil.

*Corresponding author <scdsilva@esalq.usp.br>

ABSTRACT: The concept of sward target has been used recently to characterise grazing management practices, but its efficiency to monitor and control sward structure questioned since it corresponds to a single sward structural feature, usually sward surface height. The objective of this experiment was to evaluate sward structure and its patterns of variation throughout the year on continuously stocked marandu palisadegrass swards maintained at $30 \mathrm{~cm}$ and subjected to contrasting rhythms of growth from January 2007 to April 2008. Treatments corresponded to three nitrogen application rates $\left(150,300\right.$ and $450 \mathrm{~kg} \mathrm{ha}^{-1}$ of N) plus the control (no $\mathrm{N}$ fertilisation), and were allocated to experimental units according to a complete randomised block design, with four replications. Sward herbage mass, morphological composition, leaf area index (LAI), foliage angle and light interception were evaluated. The increase in nitrogen application rates resulted in increased sward herbage mass, proportion of leaf and stem, and reduction in the proportion of dead material. These modifications were in line with the increase in LAI and reduction in foliage angle, although they did not modify sward light interception. Despite the wide range of nitrogen application rates used, there was a common pattern of variation in sward structure. Overall, changes in sward structural characteristics generated by the range of growth rhythms studied were small, indicating that sward height corresponded to an efficient way to monitor and control the grazing process and sward structure, and can be used to define targets of grazing management.

Key words: Brachiaria brizantha, nitrogen, sward structure, sward height, grazing management

\section{Características estruturais de pastos de capim-marandu submetidos à lotação contínua e ritmos de crescimento contrastantes}

\begin{abstract}
RESUMO: O conceito de alvo de manejo tem sido utilizado recentemente para caracterizar estratégias de manejo do pastejo, mas sua eficiência em permitir controle e monitoramento da estrutura do dossel forrageiro questionada desde que corresponde a uma única característica estrutural, geralmente a altura do pasto. $\mathrm{O}$ objetivo deste experimento foi avaliar a estrutura do dossel forrageiro e seus padrões de variação ao longo do ano em pastos de capim-marandu mantidos a $30 \mathrm{~cm}$ sob lotação contínua e submetidos a ritmos de crescimento contrastantes de Janeiro 2007 a Abril de 2008. Os tratamentos corresponderam a três doses de aplicação de nitrogênio $\left(150,300\right.$ e $450 \mathrm{~kg} \mathrm{ha}^{-1}$ de N) mais o controle (sem adubação), e foram alocados às unidades experimentais segundo um delineamento de blocos completos casualizados, com quatro repetições. Foram avaliadas massa de forragem, composição morfológica, índice de área foliar (IAF), ângulo da folhagem e interceptação luminosa dos pastos. O aumento das doses de aplicação de nitrogênio resultou em maior massa de forragem, proporção de folhas e colmos, e menor proporção de material morto. Estas modificações foram coerentes com o aumento registrado em IAF e a redução em ângulo da folhagem, embora não tenham resultado em variação na interceptação luminosa dos pastos. Apesar da grande amplitude das doses de nitrogênio avaliadas, houve um padrão comum de variação na estrutura dos pastos. No geral, as mudanças nas características estruturais dos pastos geradas pela amplitude de ritmos de crescimento avaliados foram pequenas, indicando que a altura do dossel correspondeu a uma forma eficiente de monitorar e controlar o processo de pastejo e a estrutura do dossel forrageiro.

Palavras-chave: Brachiaria brizantha, nitrogênio, estrutura do dossel, altura, manejo do pastejo
\end{abstract}

\section{Introduction}

During the last decade the research with tropical forage grasses changed and pastures started to be consid- ered as an ecosystem where sustainability depends on the equilibrium between its biotic and abitotic components. The concept of sward target was suggested (Hodgson and Da Silva, 2002), and new grazing manage- 
ment strategies defined based on a field indicator generated from studies where the functional responses of plants and animals were evaluated, the sward surface height (Da Silva and Nascimento Jr., 2007). Grazing management should be based on the knowledge of how plants and animals respond to variations in sward structure (Hodgson, 1985), and management practices considered as a means of generating these conditions of sward structure (Hodgson and Da Silva, 2002).

The use of a single, simple field indicator as sward height to monitor and control the grazing process may seem like an oversimplification of the process, since it is possible that, depending on edaphic and climatic characteristics, variations in spatial distribution of the vegetation may occur for a given sward height, compromising its effectiveness in representing sward structure and, therefore, its usefulness as a management target ( $\mathrm{Da}$ Silva et al., 2008).

In a previous series of experiments on continuously stocked marandu palisadegrass, swards were maintained at $10,20,30$ and $40 \mathrm{~cm}$ and received the same amount of nitrogen fertiliser. Under those conditions sward height allowed efficient control of sward structure throughout the year, and $30 \mathrm{~cm}$ was considered the ideal target for managing continuously stocked marandu palisadegrass for growing or fattening animals (Da Silva, 2004).

Against that background, the objective of this experiment was to evaluate sward structure and its patterns of variation throughout the year on continuously stocked marandu palisadegrass maintained at $30 \mathrm{~cm}$ and fertilised with doses of nitrogen as a means of generating contrasting rhythms of growth, favouring the assessment of the use of sward height as a grazing management target.

\section{Material and Methods}

The experiment was carried out in Piracicaba, state of São Paulo, Brazil (22 $42^{\prime}$ S, $47^{\circ} 37^{\prime} \mathrm{W}$ and $550 \mathrm{~m}$ a.s.l.), on a high fertile Eutric Kandiudalf. Average soil chemical characteristics (Raij et al., 1986) for the $0-20 \mathrm{~cm}$ layer were: $\mathrm{pH} \mathrm{CaCl}$ : $5.0 ; \mathrm{OM}=41.6 \mathrm{~g} \mathrm{dm}^{-3}$; $\mathrm{P}$ (ion-exchange resin extraction method) $=62.1 \mathrm{mg} \mathrm{dm}^{-3} ; \mathrm{Ca}=60.7$ $\mathrm{mmol} \mathrm{dm}^{-3} ; \mathrm{Mg}=16.0 \mathrm{mmol}_{\mathrm{c}} \mathrm{dm}^{-3} ; \mathrm{K}=6.6 \mathrm{mmol}_{\mathrm{c}} \mathrm{dm}^{-3}$; $\mathrm{H}+\mathrm{Al}=44.3 \mathrm{mmol}_{\mathrm{c}} \mathrm{dm}^{-3}$; sum of bases $=99.0 \mathrm{mmol}_{c}^{\mathrm{c}}$ $\mathrm{dm}^{-3}$; cation exchange capacity $=127.5 \mathrm{mmol}_{\mathrm{c}} \mathrm{dm}^{-3}$; base saturation $=65 \%$.

Climatic data during the experiment were collected in a Meteorological Station located at approximately 500 $\mathrm{m}$ from the experimental site (Figure 1). A water soil balance (surplus and deficit) was calculated using the monthly rainfall and average air temperature data throughout the experimental period considering a water storage capacity of $50 \mathrm{~mm}$ (Figure 2).

The Brachiaria brizantha cv. Marandu (marandu palisadegrass) swards were established in 2001 and used for a series of experiments on continuous stocking from 2001 to 2003 and another one on rotational stocking from 2004 to 2006 focussing on aspects of plant ecophysiology and grazing ecology. At the end of those experiments the area was kept under rotational stocking by beef cattle until March 2006 and then mowed at $10 \mathrm{~cm}$ in April in preparation for the present experiment based on continuous stocking management. Management target was a sward surface height of $30 \mathrm{~cm}$, a condition that, based on the results of the previous series of experiments under continuous stocking (swards maintained at $10,20,30$ and $40 \mathrm{~cm}$ ), resulted in high herbage accumulation (Sbrissia, 2004), high animal performance and productivity (Andrade, 2003), but low utilisation efficiency of the produced herbage (Gonçalves, 2002).

Monitoring of the experimental conditions started soon after mowing, and was carried out measuring sward surface height twice a week using a sward stick (Barthram, 1985). A total of 100 readings was taken from each paddock $\left(1,200 \mathrm{~m}^{2}\right)$ along four transect lines (25 points each)

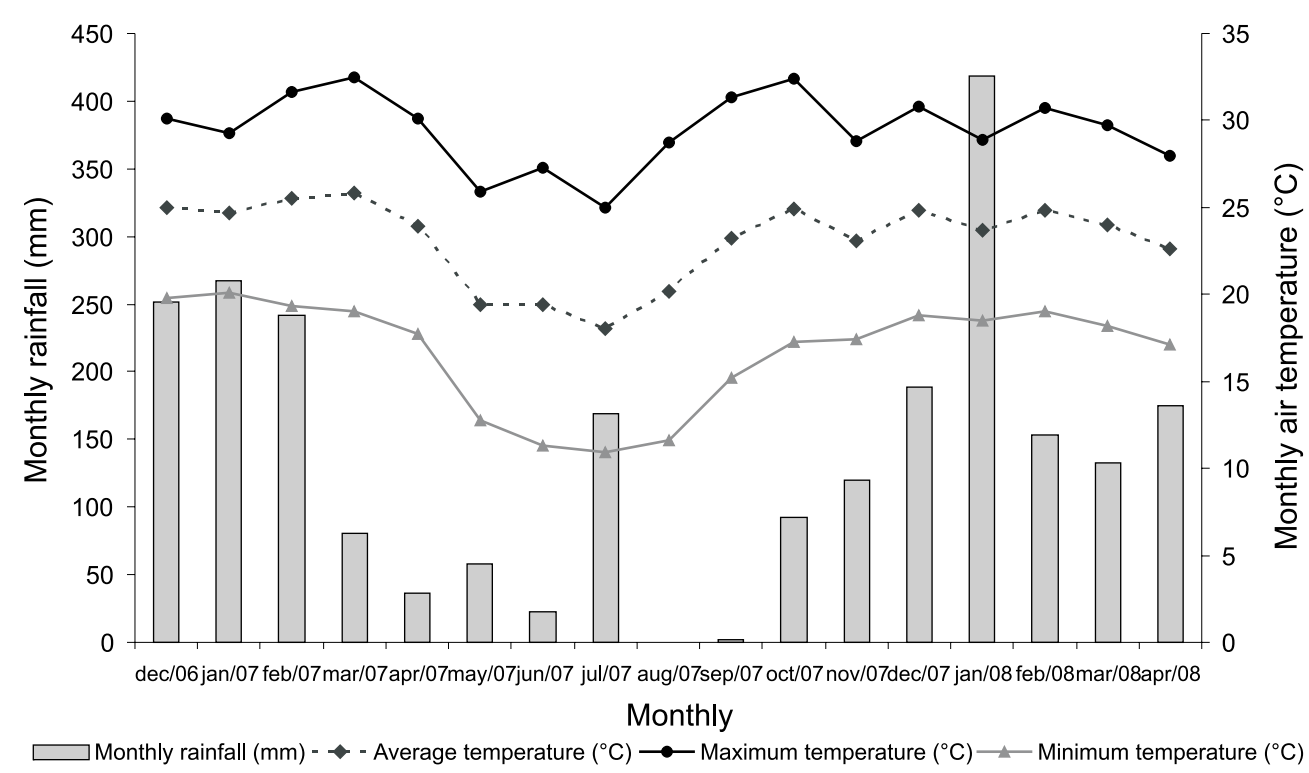

Figure 1 - Monthly means of maximum, average and minimum daily air temperatures and rainfall from December 2006 to April 2008. 


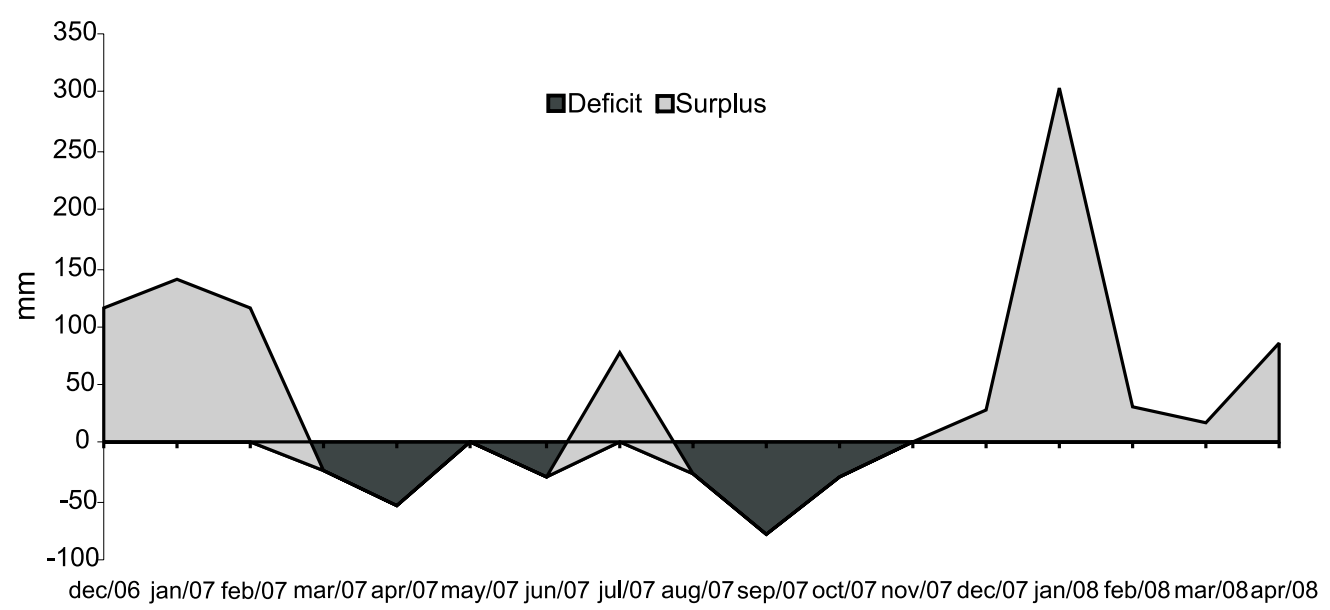

\section{Months of the year}

Figura 2 - Monthly soil water balance (calculated considering a soil water storage capacity of $50 \mathrm{~mm}$ ) from December 2006 to April 2008 (Arrows indicate time when nitrogen was applied on swards).

arranged in a zig-zag format. A tolerance range of $\pm 10 \%$ was established for variations around the target (27 to 33 $\mathrm{cm})$. As the lower limit of the range was reached, animals started to be placed on paddocks, from October 2006 onwards. The grazing method used was continuous stocking with variable stocking rate, and animals were added or removed from paddocks according to the need to maintain sward target relatively stable and around $30 \mathrm{~cm}$. Grazing was carried out by Nelore and Canchim heifers with an average initial body weight of $250 \mathrm{~kg}$.

Treatments corresponded to four rhythms of plant growth generated by the application of nitrogen fertiliser at the rates of 150,300 and $450 \mathrm{~kg} \mathrm{ha}^{-1}$ of $\mathrm{N}$ plus no fertilisation. The nitrogen fertiliser used was pure ammonium nitrate. The total dose was applied in four equal instalments throughout the year in the following dates: Year 1 - December 19, 2006; January 16, 2007; February 23, 2007 and March 23, 2007; Year 2 - December 20, 2007; January 17, 2008; February 14, 2008 and March 13, 2008. The experimental design was a complete randomised block, with four replications. Experimental measurements were initiated after all 16 paddocks (experimental units) had reached the sward target of $30 \mathrm{~cm}$ and were being continuously stocked by cattle, a condition that only happened from December 2006 onwards. For that reason, the experimental period started in January 2007 and finished in April 2008, comprising two entire consecutive pasture growing seasons (2006/2007 and 2007/2008).

Measurements of sward herbage mass, morphological composition and leaf area index were carried out throughout the experiment during five seasons of the year. These were defined based on the results from the previous series of experiments and corresponded to seasons within which general behaviour was similar but represented changes in patterns of plant responses throughout the experimental period: summer 1 (January to March, 2007), autumn/winter (April to August, 2007), early spring (September to mid-November, 2007), late spring (mid-November to December, 2007) and summer 2 (January to mid-April, 2008). Herbage samples were harvested using a $0.90 \times 0.37 \mathrm{~m}\left(0.999 \mathrm{~m}^{2}\right)$ metallic frame, which was randomly placed on three areas of the paddocks that represented the average sward condition at the time of sampling (visual assessment of sward height and herbage mass). All herbage within the frame was cut to ground level, conditioned in brown paper bags and taken to the laboratory, where their fresh weight was determined. After weighing, the three samples per paddock were combined and separated into two sub-samples, one for dry matter (DM) content determination and other for manual dissection into leaf (leaf laminae), stem (leaf sheath + stem) and dead material. Leaf laminae had their area measured using a LI-COR leaf area integrator, LAI3100 model, and the results were used to calculate sward leaf area index (LAI). In the sequence, morphological components were dried in forced draught oven at $65^{\circ} \mathrm{C}$ until constant weight, and the results used to calculate sward herbage mass ( $\mathrm{kg} \mathrm{ha}^{-1} \mathrm{DM}$ ) and morphological composition as percentage of total herbage mass.

Measurements of sward light interception and foliage angle were carried at 15-day intervals throughout the experimental period using a LI-COR canopy analyser, LAI 2000 model (LI-COR, Lincoln, Nebraska, EUA). Readings were taken from four sampling areas per paddock being 10 at ground level e one above sward canopy, totalling 40 readings at ground level and four above sward canopy.

For consistency, data for light interception and foliage angle were grouped into the same five seasons of the year used for the collection of herbage mass, morphological composition and LAI data. Analysis of variance was carried out on the grouped data using the Mixed Procedure of SAS ${ }^{\circledR}$ (Statistical Analysis System). The choice of the covariance matrix was made using the Akaike Information Criterion (AIC) (Wolfinger, 1993), and analysis performed considering nitrogen application rate, sea- 
son of the year and their interaction as fixed effects and blocks as a random effect (Littel et al., 2000). When appropriate, treatment means were calculated using the "LSMEANS" statement, and comparisons made with "PDIFF" based on a Student t test $(p<0.05)$.

\section{Results}

After swards reached the $30 \mathrm{~cm}$ target and continuous stocking commenced, average sward height was maintained relatively stable and within the pre-determined limits of variation $(30 \mathrm{~cm} \pm 10 \%)$ during the entire experimental period regardless of fertiliser use and application rate (Figure 3). Despite the relatively uniform sward height, LAI varied with nitrogen application $(p<0.0001)$, season of the year $(p<0.0001)$ and the nitrogen application $\times$ season of the year interaction $(p=0.0111)$. LAI increased with nitrogen application, characterising a clear contrast between non-fertilised or swards fertilised with $150 \mathrm{~kg} \mathrm{ha}^{-1}$ and those fertilised with 300 and $450 \mathrm{~kg} \mathrm{ha}^{-1}$, except in early spring. The lowest values of LAI for the experiment were recorded during early spring (Figure 4).

Foliage angle was affected by nitrogen application $(p=0.0012)$, season of the year $(p<0.0001)$ and nitrogen application $x$ season of the year interaction $(p=0.0359)$. Overall, there was a trend of decreasing values of foliage angle (more horizontal architecture) with increasing nitrogen application (Figure 5). However, in most cases differences were not significant, and the contrast between non-fertilised and swards fertilised with $450 \mathrm{~kg} \mathrm{ha}^{-1} \mathrm{~N}$ was more noticeable in early spring.

In spite of the variation in LAI and foliage angle with nitrogen application, sward light interception was affected only by season of the year $(p=0.0039)$, with lowest values recorded during summer 1 and highest values recorded during early and late spring and summer 2 (Figure 6). Sward herbage mass was affected by nitrogen application $(p=0.0010)$ and season of the year $(p<0.0001)$. There was no effect of the nitrogen application $\times$ season of the year interaction $(p=0.2611)$. The largest value of herbage mass was recorded in early spring and the lowest in summer 1 (Figure 7). Swards fertilised with 300 and $450 \mathrm{~kg} \mathrm{ha}^{-1} \mathrm{~N}$ had similar herbage mass values, and these were larger than those of swards non-fertilised or fertilised with $150 \mathrm{~kg} \mathrm{ha}^{-1} \mathrm{~N}$, which were also similar (Figure 8).

The percentage of leaf in sward herbage mass was affected by nitrogen application $(p<0.0001)$, season of the year $(p<0.0001)$ and nitrogen application $\times$ season of the year interaction $(p=0.0036)$. Overall, the percentage of leaf was slightly higher on swards fertilised with higher $\left(300\right.$ and $\left.450 \mathrm{~kg} \mathrm{ha}^{-1}\right)$ than lower rates $\left(150 \mathrm{~kg} \mathrm{ha}^{-1}\right.$ or no nitrogen fertilisation), except in summer 1 , when there was no difference between treatments (Figure 9). The lowest percentage of leaf in sward herbage mass was recorded in early spring. As for leaf percentage, the percentage of stem in sward herbage mass was also affected by nitrogen application $(p=0.0035)$, season of the year $(p<0.0001)$ and nitrogen application $\times$ season of the year interaction $(p<0.0001)$. In general, higher rates of nitrogen application (300 and $450 \mathrm{~kg} \mathrm{ha}^{-1}$ ) resulted in slightly higher percentage of stem in sward herbage mass than lower rates $\left(150 \mathrm{~kg} \mathrm{ha}^{-1}\right.$ and no nitrogen fertilisation), except during summer 1 , when stem percentage was relatively stable. Early spring was the season of the year when the lowest values of stem percentage were recorded (Figure 10).

The percentage of dead material in sward herbage mass was affected by nitrogen application $(p<0.0001)$, season of the year $(p<0.0001)$ and nitrogen application $x$ season of the year interaction $(p=0.0039)$. Higher rates of nitrogen application $\left(300\right.$ and $\left.450 \mathrm{~kg} \mathrm{ha}^{-1}\right)$ resulted in lower percentage of dead material in sward herbage mass than lower rates $\left(150 \mathrm{~kg} \mathrm{ha}^{-1}\right.$ and no nitrogen fertilisation), except during summer 1 , when dead material percentage was relatively stable (Figure 11).

\section{Discussion}

The low efficiency of management practices traditionally used in pastoral systems is a consequence of the

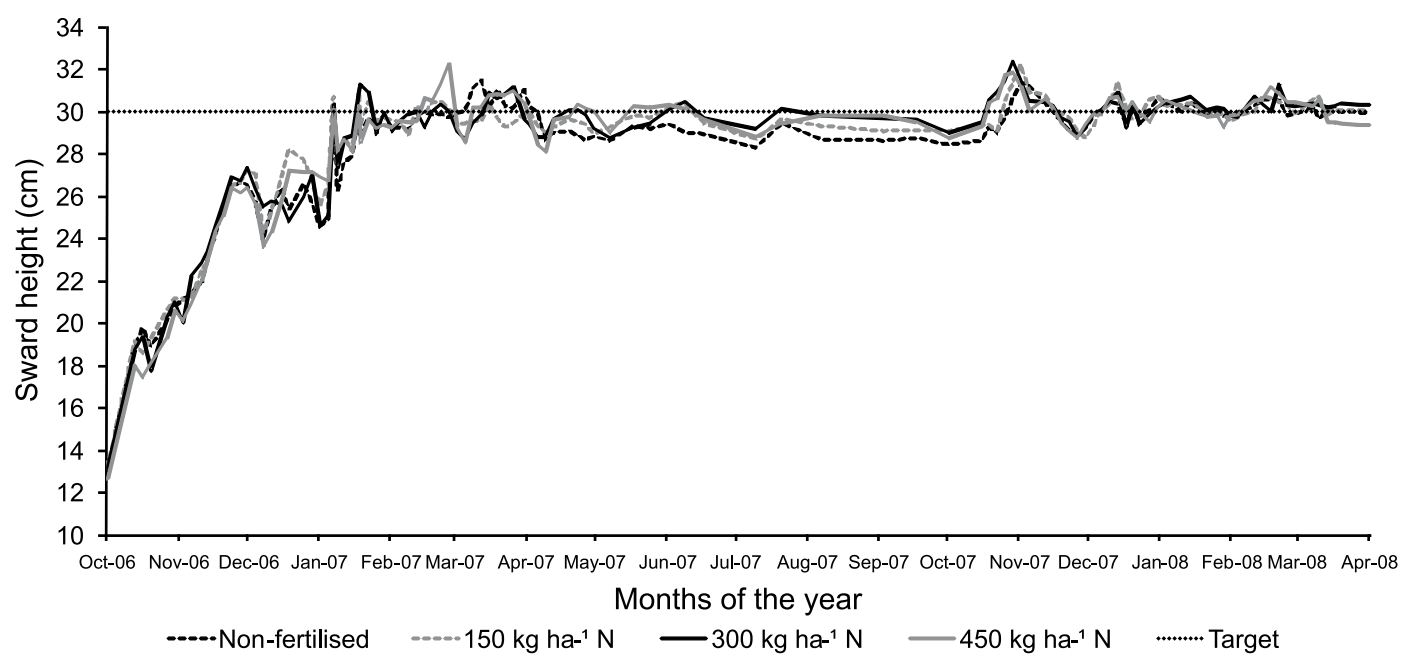

Figure 3 - Average sward height of continuously stocked marandu palisadegrass from October 2006 to April 2008. 


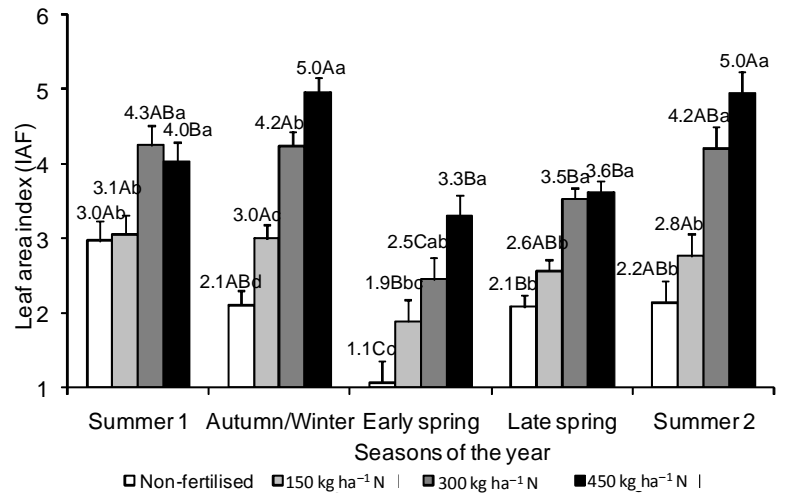

Figure 4 - Leaf area index of continuously stocked marandu palisadegrass swards subjected to contrasting rhythms of growth from January 2007 to April 2008. Lower case letters compare treatments within season of the year; upper case letters compare seasons of the year within treatment.

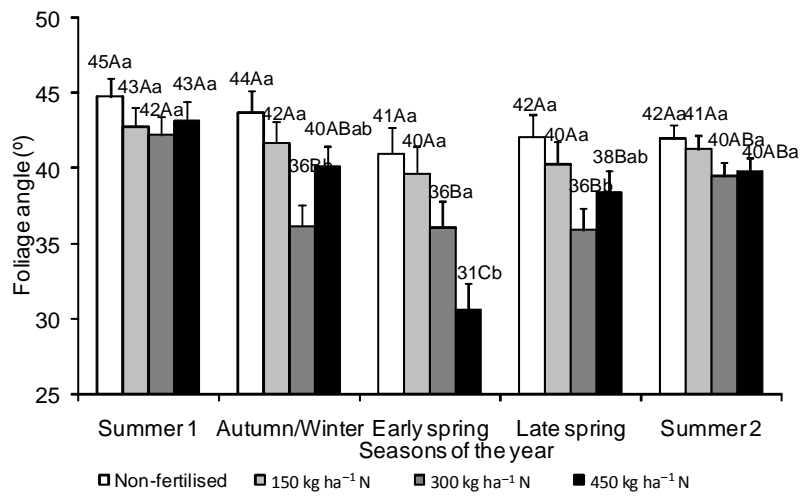

Figure 5 - Foliage angle of continuously stocked marandu palisadegrass swards subjected to contrasting rhythms of growth from January 2007 to April 2008. Lower case letters compare treatments within season of the year; upper case letters compare seasons of the year within treatment).

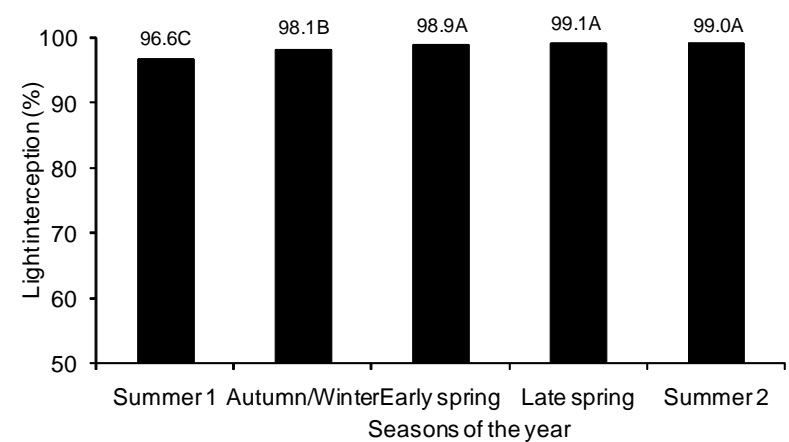

Figure 6 - Light interception of continuously stocked marandu palisadegrass swards subjected to contrasting rhythms of growth from January 2007 to April 2008. Upper case letters compare season of the year means.

lack of knowledge regarding plant and animal physiological and biological requirements (Parsons et al., 1988). Recognition of the fact highlighted the need to consider pastures as a complex ecosystem whose sustainability depends on the equilibrium between its biotic and abi-

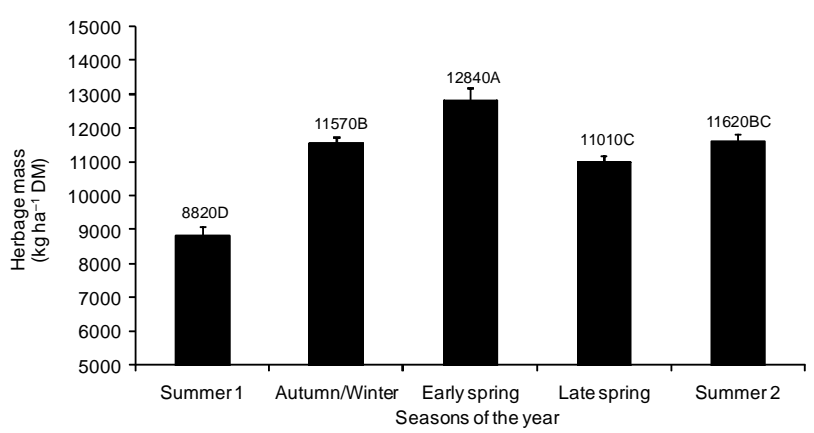

Figure 7 - Herbage mass of continuously stocked marandu palisadegrass swards subjected to contrasting rhythms of growth from January 2007 to April 2008. Upper case letters compare season of the year means.

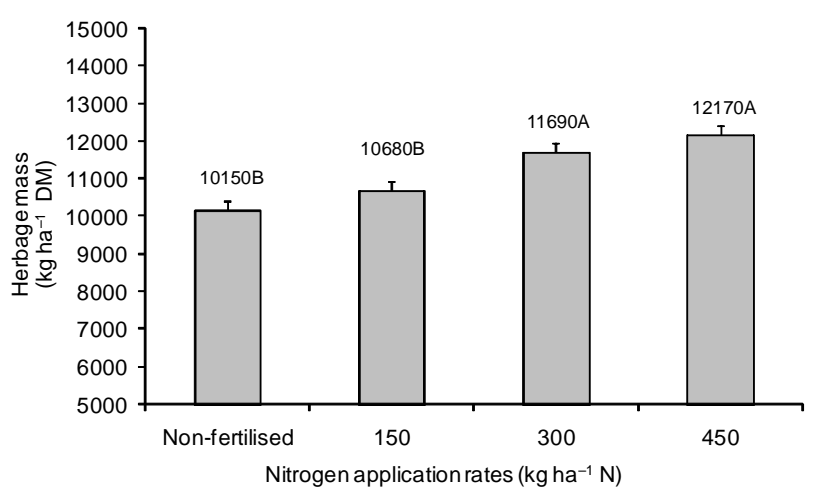

Figure 8 - Herbage mass of continuously stocked marandu palisadegrass swards subjected to contrasting rhythms of growth. Upper case letters compare treatment means.

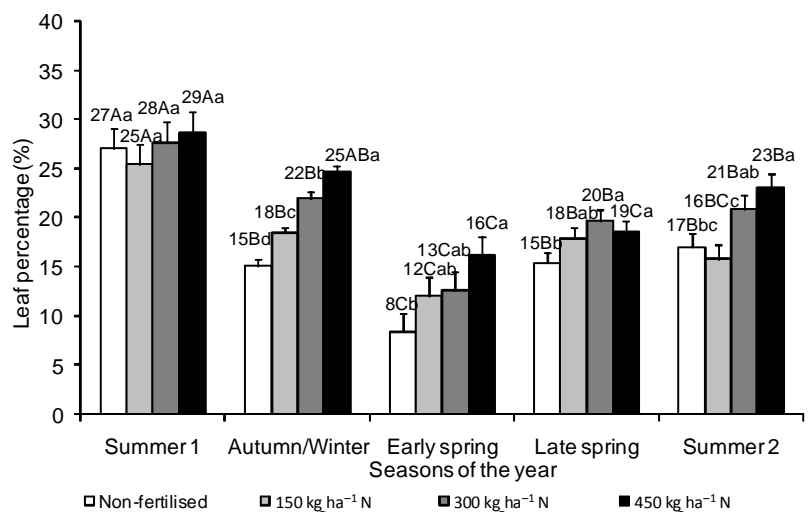

Figure 9 - Leaf percentage on the herbage mass of continuously stocked marandu palisadegrass swards subjected contrasting rhythms of growth from January 2007 to April 2008. Lower case letters compare treatments within season of the year. Upper case letters compare seasons of the year within treatment.

otic components. Such equilibrium can be described and determined from the knowledge of how plant and animal responses vary with changes in sward structure (Hodgson, 1985). This gave rise to the concept of sward target (Hodgson and Da Silva, 2002), and new strategies 
Mesquita et al.

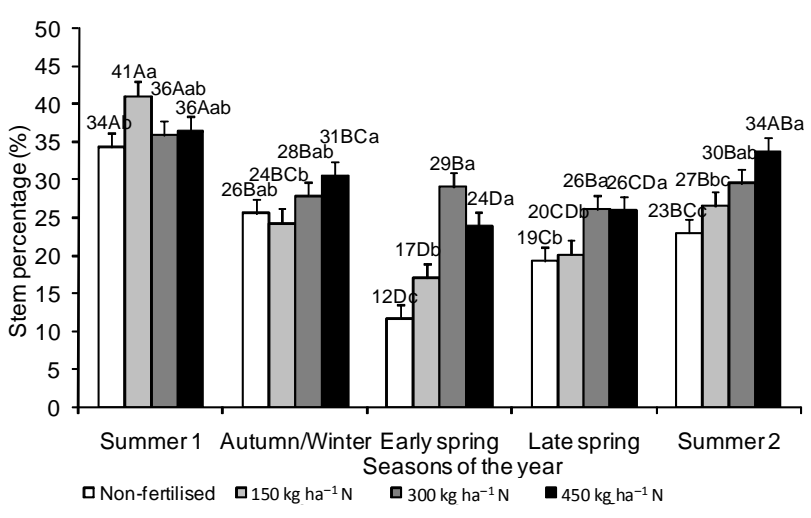

Figure 10 -Stem percentage on the herbage mass of continuously stocked marandu palisadegrass swards subjected contrasting rhythms of growth from January 2007 to April 2008. Lower case letters compare treatments within season of the year. Upper case letters compare seasons of the year within treatment.

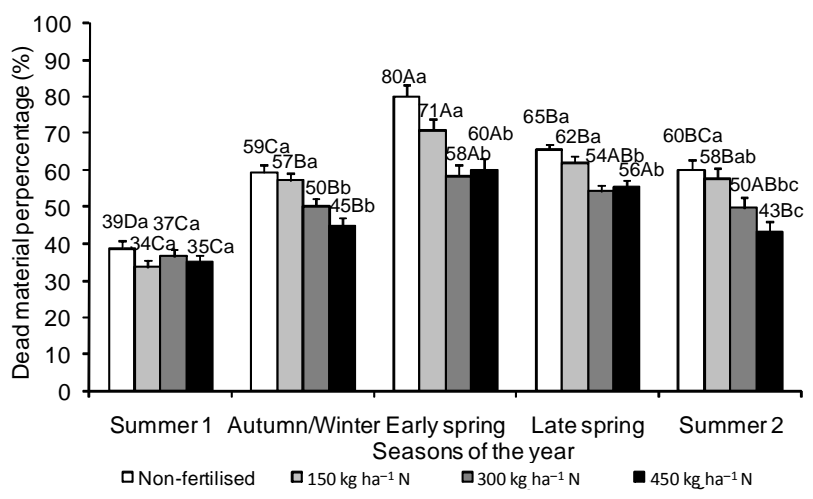

Figure 11 - Dead material percentage on the herbage mass of continuously stocked marandu palisadegrass swards subjected to contrasting rhythms of growth from January 2007 to April 2008. Lower case letters compare treatments within season of the year. Upper case letters compare seasons of the year within treatment.

for using tropical forage grasses started to be defined based on a field indicator capable of integrating the functional relations between plant and animal responses and sward structure, the sward surface height (Da Silva and Nascimento Jr., 2007).

In this experiment, sward height remained relatively stable and within the targeted range of variation planned $(30 \mathrm{~cm} \pm 10 \%)$ throughout the experimental period (Figure 3), regardless of nitrogen use and/or application rate. This ensured that variations in sward structure measured were a direct result of the nitrogen application rates tested and season of the year. Swards fertilised with 300 and $450 \mathrm{~kg} \mathrm{ha}^{-1} \mathrm{~N}$ showed larger herbage mass than those non-fertilised or fertilised with $150 \mathrm{~kg} \mathrm{ha}^{-1}$. The increase was around 5,15 and $20 \%$ on swards fertilised with 150 , 300 and $450 \mathrm{~kg} \mathrm{ha}^{-1}$ in relation to non-fertilised swards. The increase in herbage mass (Figure 8) was associated with increases in the percentages of leaf (Figure 9) and stem (Figure 10) and reduction in the percentage of dead material (Figure 11), a result in line with larger values of LAI (Figure 4) and smaller values of foliage angle (Figure 5) for swards fertilised with 300 and $450 \mathrm{~kg} \mathrm{ha}^{-1} \mathrm{~N}$ relative to those non-fertilised or fertilised with $150 \mathrm{~kg}$ $\mathrm{ha}^{-1} \mathrm{~N}$. Despite differences in sward structure, canopy light interception was similar on all swards (Figure 6). This pattern of response of forage plants to nitrogen fertilisation is well known (Mazzantti et al., 1994; Lawlor, 1995; Cruz and Boval, 2000) and is a result of increased tiller population density and growth per tiller (Nelson et al., 1977).

Higher rates of nitrogen application result in faster rhythms of plant growth that, in turn, result in large final leaf lamina length of expanded leaves (Gastal and Nelson, 1994). As a consequence, the proportion of the leaf component in sward herbage mass increases (Figure 9) and sward canopy assumes a more horizontal architecture (heavier leaves) (Figure 5) relative to lower rates of nitrogen application or no nitrogen use. Therefore, faster rhythms of plant growth, characterised by high rates of leaf appearance and elongation (Gastal and Nelson, 1994; Cruz and Boval, 2000), generate conditions for an early start of processes related with light competition inside sward canopy, which may cause an increase in stem elongation (Sbrissia and Da Silva, 2001). Stem elongation results in increased tiller internode length that, in turn, favours penetration of light into sward canopy, decreasing senescence rates and dead material accumulation. This pattern of response indicates higher utilisation efficiency on swards fertilised with high rates than those non-fertilised or fertilised with low rates of nitrogen, since a smaller proportion of growth would be lost to senescence (Mazzanti and Lemaire, 1994). However, this hypothesis still needs to be further studied. To achieve that, information on patterns of defoliation of individual tillers and plant morphogenetic responses have to be generated.

The highest values of sward herbage mass were recorded in early spring, time of the year when rainfall was lowest and there was a soil water deficit in the experimental area (Figure 2), conditions associated with high senescence (Cano et al., 2004; Euclides and Euclides Filho, 1997), favouring the accumulation of dead material (Figure 11). These are important morphological modifications in sward structure, since they result in reduced nutritive value of the herbage mass on offer and decreased rates of herbage accumulation, forcing system manager to lower stocking rate and, eventually, feed supplements to meet feed demand by the grazing animals and maintain sward target. In spite of the wide range of nitrogen application rates used, it was possible to identify a common pattern of variation in sward structure, with differences between treatments corresponding only to the magnitude of the responses. In general, the percentage of leaf and stem (Figures 9 and 10) were large and of dead material (Figure 11) small during times of the year when rainfall, temperature and light avail- 
ability were high (summer 1, late spring and summer 2 ), the inverse happening when availability of climatic growth factors was low (autumn/winter and early spring), and these differences in morphological composition of sward herbage mass were larger than those caused by the $\mathrm{N}$ fertilisation rates used.

The high percentage of leaf and low percentage of stem in herbage mass were associated with high LAI values (Figure 4) during the more favourable seasons to growth regardless of fertilisation and nitrogen application rate, except in summer 1, when swards were still adapting to grazing management imposed and the steady state condition not generated yet. The effect of season of the year on the percentage of leaf and stem and LAI is a result of the climatic factors that affect morphology and morphogenetic responses of plants, altering their patterns of nutrients distribution and determining restrictions to the size of the photosynthetic apparatus (Lawlor, 1995; Mazzanti et al., 1994; Lemaire and Chapman, 1996).

The larger values of sward herbage mass (Figure 8) and LAI (Figure 4) on swards fertilised with 300 and 450 $\mathrm{kg} \mathrm{ha}^{-1} \mathrm{~N}$ than on those non-fertilised or fertilised with $150 \mathrm{~kg} \mathrm{ha}^{-1}$ were associated with higher values of canopy light interception (Figure 6), indicating that, despite being maintained at a fairly constant height throughout the experiment, sward structure varied with season of the year and within season of the year with nitrogen fertilisation and rate of application of nitrogen fertiliser. However, although significant, most of the time variations in sward structure due to nitrogen application rates were small, since non-fertilised swards were already intercepting more than $95 \%$ of the incident light, value considered as a reference for obtaining maximum rates of net herbage accumulation for temperate grass species (Parsons et al., 1988) or net leaf accumulation for tropical grass species (Barbosa et al., 2007; Pedreira et al., 2007; Da Silva et al., 2009). In terms of animal responses, the slightly larger percentage of leaf and lower percentage of dead material on swards fertilised with high rates of $\mathrm{N}$, for the same sward height, could have positive implications to herbage intake and animal performance. On the other hand, the increased percentage of the stem under those conditions could partially or totally compensate those benefits. Confirmation of this hypothesis, however, could only be achieved through evaluations of animal ingestive behaviour, which were not carried out in this experiment.

As a conclusion, sward height provided an efficient way to monitor and control the grazing process and sward structure, regardless of nitrogen use and/or application rate, and can, therefore, be used to define targets of grazing management.

\section{Acknowledgements}

To CNPq (Conselho Nacional de Desenvolvimento Científico e Tecnológico, Brazil) and FAPESP (Fundação de Amparo à Pesquisa do Estado de São
Paulo, Brazil) for partial funding of this research, and Dra. Valéria Pacheco Batista Euclides for valiable comments and suggestions.

\section{References}

Andrade, F.M.E. 2003. Produção de forragem e valor alimentício do capim-Marandu submetido a regimes de lotação contínua por bovinos de corte. MSc. Dissertation. Universidade de São Paulo, Piracicaba, SP, Brazil. (in Portuguese with summary in English).

Barbosa, R.A.; Nascimento Jr., D.; Euclides, V.P.B.; Da Silva, S.C.; Zimmer, A.H.; Torres Jr, R.A.A. 2007. Capim-tanzânia submetido a combinações entre intensidade e frequência de pastejo. Pesquisa Agropecuária Brasileira 42: 329-340.

Barthram, G.T. 1985. Experimental techniques: the HFRO sward stick. Hill Farming Research Organization, Aberdeen, Scotland.

Cano, C.C.P.; Cecato, U.; Rodrigues, A.B.; Jobim, C.C.; Rodrigues, A.M.; Galbeiro, S.; Nascimento, W.G. 2004. Produção de forragem do capim-tanzânia (Panicum maximum Jacq. Cv. Tanzânia-1) pastejado em diferentes alturas. Revista Brasileira de Zootecnia 33: 1949-1958.

Cruz, P.; Boval, M. 2000. Effect of nitrogen on some morphogenetic traits of temperate and tropical perennial forage grasses. p.151168. In: Lemaire, G.; Hodgson, J.; Moraes, A., eds. Grassland Ecophysiology and Grazing Ecology. Centre for Agriculture and Biosciences International [CABI], London, UK.

Da Silva, S.C. Fundamentos para o manejo de pastagens de plantas forrageiras dos gêneros Brachiaria e Panicum. 2004. Anais do Simpósio sobre Manejo Estratégico da Pastagem 2. Editora Suprema, Viçosa, MG, Brazil.

Da Silva, S.C; Bueno, A.A.O.; Carnevalli, R.A.; Uebele, M.C.; Bueno, F.O.; Hodgson, J.; Matthew, C.; Arnold, G.C.; Morais, J.PG. 2009. Sward structural characteristics and herbage accumulation of Panicum maximum cv. Mombaça subjected to rotational stocking managements. Scientia Agricola 66: 8-19.

Da Silva, S.C.; Nascimento Jr., D. 2007. Ecofisiologia da produção animal em pastagens e suas implicações sobre o desempenho e a produtividade de sistemas pastoris. Anais do Simpósio sobre Manejo Estratégico da Pastagem 4. Editora Suprema, Viçosa, MG, Brazil.

Da Silva, S.C.; Nascimento Jr., D.; Sbrissia, A.F.; Pereira, L.E.T. 2008. Dinâmica de população de plantas forrageiras em pastagens. Anais do Simpósio sobre Manejo Estratégico da Pastagem 5. Editora Suprema, Viçosa, MG, Brazil.

Euclides, V.P.B.; Euclides Filho, K. 1997. Avaliação de forrageiras sob pastejo. Anais do Simpósio sobre Avaliação de Pastagens com Animais. Universidade Estadual de Maringá, Maringá, PR, Brazil.

Gastal, F.; Nelson, C.J. 1994. Nitrogen use within the growing leaf blade of tall fescue. Plant Physiology 105: 191-197.

Gonçalves, A.C. 2002. Características morfogênicas e padrões de desfolhação em pastos de capim-Marandu submetidos a regimes de lotação contínua. MSc Dissertation. Universidade de São Paulo, Piracicaba, SP, Brazil. (in Portuguese with summary in English).

Hodgson, J. 1985. The significance of sward characteristics in the management of temperate sown pastures. p. 63-66. Proceedings of the International Grassland Congress 15. Kyoto, Japan.

Hodgson, J.; Da Silva, S.C. 2002. Options in tropical pasture management. Anais da Reunião Anual da Sociedade Brasileira de Zootecnia 39. Sociedade Brasileira de Zootecnia [SBZ], Brasília, DF, Brazil.

Lawlor, D.W. 1995. Photosynthesis, productivity and environment. Journal of Experimental Botany 46: 1449-1461.

Lemaire, G.; Chapman, D. 1996. Tissue flows in grazed plant communities. p.3-36.. In: Hodgson, J.; Illius, A.W., eds. The Ecology and Management of Grazing Systems. Centre for Agriculture and Biosciences International [CABI], London, UK. 
Littel, R.C.; Pendergast, J.; Natarajan, R. 2000. Modelling covariance structure in the analysis of repeated measures data. Statistics in Medicine 19: 1793-1819.

Mazzanti, A.; Lemaire, G. 1994. Effects of nitrogen fertilization on the herbage production of tall fescue swards grazed continuously with sheep. 2. Consumption and efficiency of herbage utilization. Grass and Forage Science 49: 352-359.

Mazzanti, A.; Lemaire, G.; Gastal, F. 1994. The effect of nitrogen fertilization upon the herbage production of tall fescue swards continuously grazed with sheep. 1. Herbage growth dynamics. Grass and Forage Science 49: 111-120.

Nelson, C.J.; Asay, K.H.; Sleper, D.A. 1977. Mechanisms of canopy development of tall fescue genotypes. Crop Science 17: 449-452.

Parsons, A.J.; Johnson, J.R.; Harvey, A. 1988. Use of a model to optimize the interaction between frequency and severity of intermittent defoliation and to provide fundamental comparison of the continuous and intermittent desfolation of grass. Grass and Forage Science 43: 49-59.

Pedreira, B.C.; Pedreira, C.G.S.; Da Silva, S.C. 2007. Estrutura do dossel e acúmulo de forragem de Brachiaria brizantha cv. Xaraés em resposta a estratégias de pastejo. Pesquisa Agropecuária Brasileira 42: 281-287. van Raij, B.; Quaggio, J.A.; Silva, N.M. 1986. Extraction of phosphorus, potassium, calcium, and magnesium from soils by ion-exchange resin procedure. Communications in Soil Science and Plant Analysis 17: 547-566.

Sbrissia, A.F. 2004. Morfogênese, dinâmica do perfilhamento e do acúmulo de forragem em pastos de capim-marandu sob lotação contínua. Dr. Thesis. Universidade de São Paulo, Piracicaba, SP, Brazil. (in Portuguese with summary in English).

Sbrissia, A.F.; Da Silva, S.C. 2001. O ecossistema de pastagens e a produção animal. Anais da Reunião Anual da Sociedade Brasileira de Zootecnia 38. Sociedade Brasileira de Zootecnia [SBZ], Brasília, DF, Brazil.

Wolfinger, R.D. 1993. Covariance structure selection in general mixed models. Communications in Statistics Simulation and Computation 22: 1079-1106.

Received August 13, 2008

Accepted July 27, 2009 